\title{
Correction to: Shear properties and pore structure characteristics of soil-rock mixture under freeze-thaw cycles
}

Liyun Tang ${ }^{1} \cdot$ Gang $\mathrm{Li}^{1} \cdot{\text { Zhen } \mathrm{Li}^{1} \cdot \text { Long } \mathrm{Jin}^{2} \cdot \text { Gengshe Yang }}^{1}$

Published online: 4 March 2021

(C) Springer-Verlag GmbH Germany, part of Springer Nature 2021

Correction to: Bulletin of Engineering Geology and the Environment (2021) https://doi.org/10.1007/s10064-021-02118-4

The original article contains an error. On page 2, the citation

"Wgeruang (2003)" should be changed to "Wang (2003)".

The original article has been corrected.

The online version of the original article can be found at https://doi.org/ 10.1007/s10064-021-02118-4

Liyun Tang

tangly@xust.edu.cn

1 School of Architecture and Civil Engineering, Xi'an University of Science and Technology, Xi'an 710054, China

2 CCCC First Highway Consultants Co. LTD, Xi'an 710004, China 